The Council of the American Meteorological Society invites members of AMS to submit nominations for consideration by the committees listed below. The names of all individuals nominated, together with background data on the individuals (limit to one page), should be sent to the appropriate committee chairman.

The specifications for all awards are set forth in the August 1986 BULlETIN, starting on page 988.

\section{Nominating Committee}

The Committee's function is to submit to the Council the names of individuals for 1) the office of President-Elect for a term of one year starting at the close of the 68th Annual Meeting (January 1988), and 2) four positions on the Council for a term of three years starting at the close of the 68th Annual Meeting. Nominations must be submitted prior to 1 April 1986 to:

\author{
Nominating Committee \\ Acting Secretary-Treasurer \\ American Meteorological Society \\ 45 Beacon St. \\ Boston, MA 02108
}

\section{Committee on Fellows}

The Committee's function is to submit to the Council the names of individuals for election to Fellow.

Article III, Section 6, of the AMS Constitution provides that those eligible for election to Fellow shall have made outstanding contributions to the atmospheric or related oceanic or hydrologic sciences or their applications during a substantial period of years. The names of nominees for Fellow remain on the Committee's active list for three years. A nomination form, which is available on request from AMS headquarters, should be used.

Nominations for Fellow must be submitted prior to 1 June 1987 (limit to one page) to:

\author{
Committee on Fellows \\ Acting Secretary-Treasurer \\ American Meteorological Society \\ 45 Beacon St. \\ Boston, MA 02108
}

\section{Awards Committee}

The Committee's function is to submit to the Council the names of individuals for the Society's awards. The names of the nominees for awards remain on the Awards Committee's active list for three years. Nominations must be submitted before 1 June 1987 to:

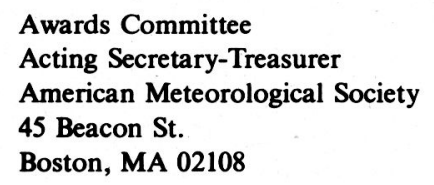

Nominations for the following five awards are submitted to the Awards Committee by the committees shown below. Nominations for these awards with supporting documentation should be sent to the appropriate committee chairman.

\title{
The Award for Outstanding Service by a Weather Forecaster
} The Charles L. Mitchell Award
for long-term service by persons engaged in
weather forecasting activities and

The Award for an exceptional specific prediction and

The Francis W. Reichelderfer Award for distinguished public service contributions by personnel of the weather services

Nominations for these awards with supporting documentation must be submitted prior to 1 May 1987 to:

\author{
AMS Committee on Weather Analysis \\ and Forecasting \\ Acting Secretary-Treasurer \\ American Meteorological Society \\ 45 Beacon Street \\ Boston, MA 02108
}

\section{The Award for Outstanding Contribution to the Advance of Applied Meteorology}

Nominations for the a ward with supporting documentation must be submitted prior to 1 May 1987 to:

\author{
AMS Board on Private Sector Meteorology \\ Acting Secretary-Treasurer \\ American Meteorological Society \\ 45 Beacon St. \\ Boston, MA 02108
}

\section{The Award for Outstanding Service by a Broadcast Meteorologist}

Nominations for the a ward with supporting documentation must be submitted prior to 1 May 1987 to:

\author{
AMS Board of Broadcast Meteorology \\ Acting Secretary-Treasurer \\ American Meteorological Society \\ 45 Beacon Street \\ Boston, MA 02108
}




\section{The Award for Outstanding Achievement in Biometeorology}

Nominations for the a ward with supporting documentation must be submitted prior to 1 May 1987 to:

Committee on Biometeorology and Aerobiology

Acting Secretary-Treasurer

American Meteorological Society

45 Beacon St.

Boston, MA 02108

\section{The Sverdrup Gold Medal}

Unlike other awards, the Sverdrup Medal is awarded by the President of the Society on the advice of an international committee. Nominations for the award with supporting documentation must be submitted prior to 1 May 1987 to:

Sverdrup Gold Medai Committee

Acting Secretary-Treasurer

American Meteorological Society

45 Beacon Street

Boston, MA 02108

\section{Undergraduate Awards and Scholarships}

The undergraduate awards and scholarships, the eligibility criteria, and the nomination processes are described on page 1020 of the August 1986 issue of the BULLETIN. The recipients are selected by the Committee of Judges for Undergraduate Awards. Nominations with supporting documentation should be received prior to 15 June 1987 by:

AMS Committee of Judges for Undergraduate Awards Acting Secretary-Treasurer American Meteorological Society

45 Beacon Street

Boston, MA 02108

\section{The Robert Leviton Award}

The Robert Leviton Award is presented for the best student paper on the development or evaluation of atmospheric instrumentation or measurements. The eligiblity criteria and the nomination process are described on page 989 of the August 1986 issue of the BULLETIN. Nominations with supporting documentation should be sent prior to $1 \mathrm{May}$ 1987 to:

Committee on Atmospheric Measurements

Acting Secretary-Treasurer

American Meteorological Society

45 Beacon Stret

Boston, MA 02108

\section{at AMS headquarters}

On 2 January, Zeng Xiaomei and Zhiang Jun Xue, of the State Meteorological Administration, People's Republic of China, who are studying in the United States, visited AMS headquarters.

Executive Director Kenneth C. Spengler and his Assistant and Meetings Manager, Evelyn Mazur, went to New Orleans on the 8th for the society's 67th Annual Meeting and associated conferences. Arriving later to assist with the meetings were Barry C. Mohan, controller, and Patricia Gallagher, Meetings Department. The Sixth Conference on Meteorological Observations and Instrumentation was cosponsored by the World Meteorological Organization (WMO), and the Third International Conference on Interactive Information and Processing Systems for Meteorology, Oceanography, and Hydrology was cosponsored by WMO, the Marine Technology Society, and the Office of the Federal Coordinator. The WMO sent representatives from Venezuela, Kenya, Brazil, and Turkey.

The Search Committee met on Friday morning, 9 January; the Executive Committee on the afternoon of the 9th and the morning of the 10th; and the Council on the afternoon of the 10 th and 11 th. AMS Counsel Robert E. McLaughlin attended the meetings of the Executive Committee and Council. The Annual Meeting began on Monday, the 12th, the date on which the Annual Business Meeting was also held. On the same day, the Scientific and Technological Activities Commission (STAC) held a luncheon at which the chairmen of the various STAC committees were present. Also on the 12th, the Education and Manpower Commission held a luncheon, attended by members of the Board of Meteorological and Oceanographic Education in Universities, Board of School and Popular Meteorological and Oceanographic Education, and Board on Women and Minorities, who were meeting that day. In addition, during the week there were meetings of the AMS Planning Commission, Investment Committee, 1987 Nominating Committee, Committee on Measurements, Board of Certified Consulting Meteorologists, ad hoc Committee on Global Change, Committee on Meteorological Aspects of Aviation and Aerospace Vehicles, AMS/EPA Steering Committee, and the 1988 IIPS Conference Planning Committee. There were also meetings of various panels and committees of the Federal Coordinator's Office, National Academy of Sciences, University Corporation for Atmospheric Research, and the National Oceanic and Atmospheric Administration. There was a breakfast meeting of Certified Consulting Meteorologists and a luncheon meeting of the National Council of Industrial Meteorologists.

A feature of the Annual Meeting was a celebration of the anniversary of four decades of the atmospheric sciences, the meteorological profession, and the American Meteorological Society, arranged by President Smagorinsky, and featuring past Presidents Philip D. Thompson, Verner E. Suomi, Richard E. Hallgren, and Thomas F. Malone as speakers. An AMS Past Presidents' dinner was held on the evening of 13 January, attended by 20 AMS presidents: Malone, Thompson, Suomi, Benton, Bollay, Blackadar, Reed, Kellogg, Atlas, Baum, Cressman, Newton, Fleagle, Hallgren, Droessler, Bierly, Murino, Smagorinsky (president), Kaehn (president-elect, 1986), Braham (president-elect, 1987), and Executive Director Spengler.

Other meeting highlights included an AMS luncheon featuring teleconferencing, AMS Awards Banquet, and combined book displays and commercial exhibits.

Chairman Joanne Simpson of the Scientific and Technological Activities Commission spent 30 January at the headquarters, conferring with Spengler on various STAC activities and making her final 1987 appointments to the STAC committees. 